\title{
XV. Experiments on charcoal
}

\section{Clement \& Desormes}

To cite this article: Clement \& Desormes (1802) XV. Experiments on charcoal, Philosophical Magazine Series 1, 13:49, 67-73, DOI: 10.1080/14786440208676094

To link to this article: http://dx.doi.org/10.1080/14786440208676094

$$
\text { 册 Published online: } 18 \text { May } 2009 .
$$

Submit your article to this journal 전

LII Article views: 2

Q View related articles $\asymp$ 
fun, or an occultation of a fixed ftar. Dr. Olbers was the firft who proved, in 1787 , that the comets of 1532 and 1661 were totally different ; confequently, that neither of them could be expected in the year I789. Aftronomy, therefore, is indebted to Dr. Olbers for having cleared up this point of fo much importance. He showed how uncertain the return of thefe comets is ; and that it is no fault in the exalted fcience of aftronomy, if predictions, which aftronomers ought never to have ventured to make, are not accomplifhed.

From Vienna Dr. Olbers proceeded to Prague and Drefden, and returned thence to Bremen, where he fettled as a phyfician, and where he foon acquired the confidence of his fellow-citizens, both on account of his fuccefsful practice and of the integrity and affability of his character. Since that time aftronomy has been only the amufement of his leifure hours, or a fort of recreation, to relieve and unbend the mind after the fatigue of his profeffional duties.

We fhall add to this fhort fketch, that Dr. Olbers lately difcovered another planet, or, perhaps, comet, for the point feems not yet determined, of which fome account was given in the laft two numbers of the Philofophical Magazine.

\section{Experiments on Cbarcoal. By CLement and Desormes *.}

$\mathrm{I}_{\mathrm{T}}$ $\mathrm{T}$ is generally believed that the charcoal obtained by the decompofition of organic matters ftill contains, notwithftanding the detion of the ftrongeft heat to which it can be fubjected, fome remains of the volatile principles to which it was united.

This opinion is founded upon this circumftance, that by the combuftion of charcoal water is fonetimes obtained, which feems to prove the prefence of hydrogen; and that to form carbonic acid with charcoal lefs oxygen is required than with the diamond; which might induce a belief that fome of it exifted already in the charcoal.

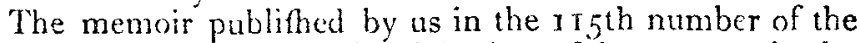
Annales de Chimile, and of which the refults are nearly the fame as thofe obtained by Mr. Cruikflank, announces the gafeous oxide of carbon as free from hydrogen.

Several chemitts, convinced of the prefence of hydrogen in charcoal, have fuppofed that this gas is a triple combination of carbon, oxygen, and hydrogen, and that its inflammability arifes from the laft-mentioned principle.

* From the Ama'es ale Clbimie, No. 125 . 
It appeared to us of importance to make fome experiments on this fubject, and we propofed the following queftions:

Does hydrogen exilt in charcoal when properly made? Are the various kinds of charcoal indebted for their differences to the quantities of oxyon which they contain?

We employed two methous to conse to the folution of thefe problems: the action of oxygen, and that of fulphur.

\section{First Method. Afzion of Orygen.}

In our memoir on the gafeous oxide of carbon we gave an account of experiments on the combution of charcoal in clofe veffels in which no water was depofited. It is, however, poffible that fome was produced, but that it became diffolved in the carbonic acid gas, in which a great diffolving power is generally obferved.

In repeating the combuftion of different kinds of charcoal properly made, but of which fome remained expofed to the air, we remarked that the latter fuffered a great deal of water to evaporate merely by the action of the heat, and that during their combuftion it was not produced in fufficient quantity to be depofited. Thofe which had been carefully protected from the action of humidity cxhibited no traces of $i t$.

This proved to us that the water obferved during the consbuftion of charcoal previoully exifted, and that it had bern taken up by that fubftance, the bycrometric property of which, long known, has been confirmed by C. Guyton in the Encyclopedie Metbodique.

We acain afiured ourlelves that charcoal of white wood well made*, weighing 4 grammes, by remaining expofed to the atmofphere even during dry weather, increated in weight 0.2 grammes. When heated, the water is expelied; which may be weighed, and which forms more than three-fourths of that augmentation. The remainder is air, which may be difengaged either by heat or by expolure of the charcoal in a vacuum. It may be realily conceived that thete phenomena, which depend on the fate of the atmolphere, the texture of the charcoal, and the lime of its expofure to the air, mutt be exceedingly variable.

It is then certain that, if water is produced in the com. buftion of charcoal, it can exift only in the ftate of vapour in the grafes which refult trom it.

It became a matter of importance to know what quantity of water thefe gafes might contain. M. de Saufure

ir We confider charcoal to be fo, when, after a firft carbunization, it has bete expofid for an hour to the action of a ftrong furmace. 
anmounces*, that, the temperature and preffure being equal, atmofpheric air, hydrogen and carbonic acid gas, when moift affect the hair hygrometer in the fame manner; but as this inftrument indicates only the degree of faturation; and not the quantity of water, we thought it our duty to make fome experiments for the purpofe of afcertaining this quantity.

The property which concrete muriate of line has to take moifture from the gafes withont altering them, induced us to make chuice of it as the means of deficcation.

We made ule of the apparatus generally employed. It confifts of a glafs tube containing the concrete muriate of lime, the weight of which is known, and throngh which the gas is made to pafs. In order to be certain of their complete faturation, we made them pafs through a jar filled with water, and placed immediately before the muriate of lime, the temperature of which was the fame as that of the atmofphere and of the gafes. It was always 12 or 13 degrees of the centigrade thermometer, and the preffure from 762 to 765 millimetres: the otizer circumftances were alfo as equal as poffible.

The following is a table of the deficcations which we made:

\begin{tabular}{|c|c|c|c|}
\hline Gafes deficcared. & $\begin{array}{l}\text { If ster depolited } \\
\text { by } 36 \text { Litres. }\end{array}$ & \multicolumn{2}{|c|}{$\begin{array}{l}\text { Water wancu would be de- } \\
\text { pofited by a Cubic Foot. }\end{array}$} \\
\hline $\begin{array}{l}\text { Atmofpheric Air } \\
\text { Oxygcn Gas - } \\
\text { Hydrogen - - } \\
\text { Azote - - - } \\
\text { Carbonic Acid, }\end{array}$ & $\begin{array}{c}\text { Grammes. } \\
0.33 \\
0.34 \\
0.34 \\
0.33 \\
0.33\end{array}$ & $\begin{array}{c}\text { Grammes. } \\
0.3^{1} 3 \\
0.3^{2} 3 \\
0.3^{2} 3 \\
0.313 \\
0.313\end{array}$ & $\begin{array}{c}\text { Grains. } \\
5 \cdot 89 \\
6 \cdot 08 \\
6 \cdot 08 \\
5 \cdot 89 \\
5 \cdot 89\end{array}$ \\
\hline
\end{tabular}

The carbonic acid, paffing through the flafk of water defitined to moiften it as much as poffible, would have been there diffolved; but we had previoufly faturated it, fo that there really paffed upon the muriate of lime as much of that gas as of the others.

It is here feen that the quantities of water depofited by each kind of gas were nearly the fame, and the differences can be afcribed only to the nuavoidable imperfection of the procefs. Thus it is certin that equal volumes of very different gafes depofit the fame quantity of water.

It remained to know whether the quantitics of water which cannot be taken from gafes by deficcation are equal; but it was almolt impoffible to afcertain this point by a * EDai jar l'Hyrometrie chap. ix. of the fecond effy. E 3 direct 
direct experiment, fince the gafes cannot be obtained perfectly dry.

From analogy we were inclined to think, that if the gafes abfolutely contained the fame quantity of water, they ought alfo to contain equal quantities of the liquids which are volatilized by their contact, fuch as alcohol and ether.

The action of the elaftic fluids on the latter being very great, it was eafy to form an exact opinion of it. We therefore made experiments, from which it refults, that, temperature, preffure, and other circumftances, being the fame, all the gafes of which we have here fpoken, hydrogen as well as the carbonic acid, equally favour the evaporation of ether; that is to fay, that in equal fpaces occupied by any gas whatever, the fame quantity of this liquid may be there reduced to the elaftic ftate, and produce the fame expanfion. The cafe is the fame with alcohol, but the quantity evaporated is much lefs than that of ether *.

The nature of the gas, then, has no influence on the property which they have of vaporizing ether and alcohol, as it depends only on the temperature and preffure. It is probable that the cafe is the fame with the evaporation of water. If it were potfible, indeed, to exercife on the ethereal or alcoholized gafes an action fimilar to that of the muriate of lime on humid gafes; that is to fay, if the ether or alcohol could be taken away by fimilar means, they might be equally deprived of it; but, as we took from the gafes the fame quantity of water, there is great reafon to prefume that it is abfolutely the fame.

This being the cafe, it appears to us that if well made charcoal, not moift, be burned with dried oxygen, and if the gas produced by the combuftion thould not contain more water than what the abforbing falt had left in the oxygen before its being employed; that is to fay, if it hould pafs upon a fimilar quantity of falt without augmenting its weight, we fhould be almoft certain that the combuftion of charcoal would produce no water: we therefore made the following experiment :

Into a very long glais tube placed upon a fmall furnace we introduced 4.50 grammes of charcoal of common wood heated in a furnace for an hour, and not yet cooled. To the extremities of the tube we adjufted two others containing the fame quantity of muriate of lime: the latter were im-

* The interefting phxnomena exhibited by the action of gafes on the liquids induced us to make experiments, which we hall give an account of in anutuer memoir. 
merfed in a mixture of ice and marine falt kept conftantly at 7 or 8 degrees below zero of the centigrade thermometer. To one of them was adapted an empty bladder, and to the other a fecond containing $: 2$ litres of oxygen.

The great tube being heated, at the place where the charcoal was the gas was made to pafs; and, when the combuftion was completed, a fingle atom of water was not depofited. The tube containing the muriate of lime, which had traverfed the oxygen before it was employed, having been weighed, was found to be increafed 0.13 grammes; that is, 0.02 more than it ought to have been according to the above table of deficcations; which arofe from the cold experienced by the gas. The muriate of lime traverfed by the product of the combuftion, which ought to have contained water, was not increafed more than 0.02 grammes. This was fill owing to the moifture taken by the charcoal from the atmofphere at the time of its introduction into the tube. But, if we thould choofe to believe that this quantity was produced by the combuftion, as it contained only 0.003 grammes of hydrogen, arifing from 4.50 grammes of charcoal, there would exilt in 100 grammes but 0.065 grammes; that is to fay, $\frac{1}{5} \bar{\delta} \bar{C}$, a quantity inappreciable.

C. Berthollet, in a letter printed in the Bibliotbeque Britanniquie*, fixes at 0.0902 grammes, or $I^{*} 7$ grain, the hydrogen contained in $1.968_{3}$ litres, or 100 cubic inches of inflammable gas, arifing from the reduction of the oxide of zinc by charcoal. But this quantity of gafeous oxide of carbon weighs nearly $2 \cdot 2,78$ grammes, and contains I. 139 grammes of charcoal, and as much oxygen. This charcoal ought to contain, therefore, the 0.0902 grammes of hydrogen; that is to fay, in 100 parts there ought to be $7.9 \mathrm{I}$ of hydrogen. C. Berthollet, then, has fixed higher than is indicated by experiment the quantity of hydrogen contained in carbonic acid gas, and confequentily in charcoal. We have, indeed, feen that we can fuppofe in the latter body at molt $0^{\circ} 065$ per cent.

This experiment, made with the greatef exactnets poffible, ftill proves that 100 parts of carbonic acid confift nearly of 28 parts of carbon and 72 of oxygen-a refult given by the celebrated Lavoifier; and if he obtained water in that combuftion, it ought not to occafion any error in the fractions of the refult, its exiftence being, as we have already faid, anterior to the act of combuftion.

Being defirous to know whether all kinds of charcoal, like that of wood, might be freed by fire from all the hydrogen combined with them, we found that the charcoal of fugar,

$$
\begin{gathered}
\mathrm{N}_{\mathrm{N}} \mathrm{I}_{4} . \\
\mathrm{E}
\end{gathered}
$$


wax, and animal matters, after being fubjected to the action of a ftrong heat, were perfectly fimilar to common charcoal, for, like it, they produced no water by conbuftion. Our intention in making thefe experiments not only was to afcertain whether thcfe kinds of charcoal were uniterl with hydrogen, but alfo to determine the relative quantities of oxygen they might contain above that neceffary to convert them into carbonic acid:

But all thofe kinds of charcoal above mentioned, as well as coak, plumbago, and anthracite, required nearly the fame quantity of oxygen. The following is the refult of the experiments :

The apparatus was the fame as that employed for the combuftion of the charcoal of wood. It will, perhaps, not give complete fatisfaction, on account of the fufpicion generally entertained of the permeability of bladders : we fhall, however, obferve, that thofe which we employed were prepared in fuch a manner as not to fuffer the gas contained in them to efcape. Befides, the refults which we obtained, and of which we hall give an exact account, are fo agreeable to thofe of Lavoifier, and to that given to us by the combution of the charcoal of wood in a balloon filled with oxygen, that they may with certainty be depended on.

\begin{tabular}{|c|c|c|c|c|c|c|c|}
\hline \multirow{2}{*}{$\begin{array}{l}\text { Kinds of } \\
\text { Charcodl } \\
\text { burnt. }\end{array}$} & \multicolumn{2}{|c|}{$\begin{array}{l}\text { Quantities } \\
\text { empioyer? }\end{array}$} & \multicolumn{2}{|c|}{ Carbonic Acid, } & \multirow[b]{2}{*}{$\begin{array}{l}\text { Lors ne- } \\
\text { gleeted. }\end{array}$} & \multicolumn{2}{|c|}{$\begin{array}{l}\text { A huodred Parts } \\
\text { of Caibonic Acic } \\
\text { are compored of }\end{array}$} \\
\hline & Cuarcoal & Oxygen. & $\begin{array}{l}\text { which } \\
\text { mght to } \\
\text { huvere- } \\
\text { fulted. }\end{array}$ & $\begin{array}{l}\text { which } \\
\text { actually } \\
\text { relulted. }\end{array}$ & & Charcoal & Oxygen. \\
\hline & Gram. & Gram. & Gram. & Gram. & Gran. & & \\
\hline of Sugar & $1 \cdot 63$ & $3 \cdot 93$ & $5 \cdot 56$ & $5 \cdot 46$ & 0.10 & $29 \cdot 3$ & 70.7 \\
\hline Of $W \cdot a x$ & 1.05 & 2.72 & 3.77 & $3 \cdot 65$ & 0.12 & $27 \cdot 8$ & $72 \cdot 2$ \\
\hline Plombago & $2 \cdot 44$ & $6 \cdot 3^{6}$ & $8 \cdot 80$ & $8 \cdot 80$ & 0.00 & $27^{\circ} 8$ & $72 \cdot 2$ \\
\hline $\begin{array}{l}\text { Anthracite } \\
\text { Animal }\end{array}$ & 2.05 & $5 \cdot 16$ & $7 \cdot 21$ & $7 \cdot 21$ & 0.00 & $28 \cdot 4$ & $71 \cdot 6$ \\
\hline Charcoal & $1 \cdot 5.5$ & 4.08 & $5^{.63}$ & $5 \cdot 68$ & 0.00 & $26 \cdot 9$ & $73 \cdot I$ \\
\hline
\end{tabular}

The combution of plumbago was the mot interefting. The whole was not burnt. The portion which remained had become of a pale black colour exactly like charcoal : at fome parts of its furface it appeared that the texture of its farts had become lefs compact, and that the black colour was entirely owing to this attenuation. 
Many fubftances which have a fine fplendour become tarnithed when fcraped: oxygen, by fcratching, as we may fay, the plumbago, produces in it fmall vacuities which difperfe the rays of light, and fuffering them no longer to be reflected towards the eye but in a fmall quantity: they therefore produce only a weak fenfation, and the body is judged to be tarnithed.

Befides this experiment, in which the black colour generally obferved in the carbonaceous principle feems to us to be owing to its divifion and its texture, we have had occafion to fee the charcoal of turpentine and wax, which are commonly fo black and dull, become brilliant like plumbago when their parts became more compact.

It is known that Prieftey, that illuftrious obferver, was acquainted with this charcoal of turpentine, and which he pofitively called white charcoal.

Thus charcoal, whatever be its texture or colour, if it has been heated, is always the fame, contains no hydrogen, and requires for its combuftion the fame quantity of oxygen. The alkaline or earthy matters, which may vary the carbonaceous principle without making any change in it, is not confidered.

Thefe experiments, indeed, do not prove that the diamond does not make an exception; but they give us reafon to wilh for a new combuftion of that body, which is too dear to be fubjected to this procefs on a large fcale.

[To be continued.]

XVI. Notices refpecting New Books.

Pbilofopbical Tranfactions of the Royal Society of London for the Year 1802 . Part i.

$\mathrm{T}$

$\mathrm{HE}$ prefent part, which is extremely interefting, contains as follow:-1. The Croonian Lecture. On the Power of the Eye to adjuft itfelf to different Diftances when deprived of the Cryftalline Lens. By Fverard Home, Efq. I.R.S.-2. The Bakerian Lecture. On the Theory of Light and Colours. By Thomas Young, M.D. F.R.S. Profeffor of Natural Philofophy in the Royal Inftitution.-3. An Analyfis of a mineral Subftance from North America, containing a Metal hitherto unknown. By Charles Hatchett, Efq. F.R.S.-4. A Defcription of the Anatomy of the Ornitborynclous paradous. By Everard Home, Efq. F.R.S.5. On the Independence of the analytical and geometrical Methods of Inveltigation; and on the Advantages to be de- 